UDC 130.2, 72.01, 711.4.01

\author{
I. O. MERYLOVA ${ }^{1 *}$, K. V. SOKOLOVA ${ }^{2 *}$ \\ 1*Prydniprovska State Academy of Civil Engineering and Architecture (Dnipro, Ukraine), e-mail iryna.merylova@gmail.com, \\ ORCID 0000-0003-2019-0780 \\ ${ }^{2 *}$ Prydniprovska State Academy of Civil Engineering and Architecture (Dnipro, Ukraine), e-mail \\ sokolova.katerina8@gmail.com, ORCID 0000-0002-3158-8957
}

\title{
A HUMAN IN THE URBAN SPACE OF THE GLOBALIZED WORLD
}

Purpose. The purpose of the research is to define certain interaction features between a human and the urban environment in the global world. Theoretical basis. The study in based on the investigations of contemporary researchers in social philosophy and urban science, as well as social scientists of Chicago School. Originality. The originality of the research is to analyze the "human-urban space" system in terms of the influence of local space of the global world on the human identity formation and preservation. Conclusions. Modern information technologies have significantly contributed into changes in the culture, society, individual consciousness and perception. They have given them absolutely global character and reorganized the value and standard system of the individual. As a result, it caused the identity crisis, so typical of the postindustrial society. Thus, one of the possible ways to overcome the crisis is to harmonize the interaction in the "human-urban space" system as an area of individual space of human social and cultural identity.

Keywords: cultural globalization; human; communicative space; local urban science; city, cognitive approach to urban science; identity crisis

\section{Introduction}

Today, globalization is better perceived as an exact fact but not a scientific theory, which is not clearly understood, than before. Technological revolution has united the world in information, culture, moral and ethical values in economic and physical terms. Information technologies are the foundation for a single and unified communicative space with its certain behavior standards, world perception and view of life. They have established a new social environment beyond the system of local space, time and action, which is global.

This study is focused on the analysis of humanistic aspect of globalization: the issues of human cultural identification in terms of global culture formation, rejection of local cultural mental sets, as well as the gap between two levels of existence - real and virtual, have been considered.

The paper deals with the urban concepts according to which the human space is perceived in the context of his associative and sensitive mental sets. Urbanization, as a local manifestation of globalization, helps consider the issues of the human perception of the urban space, his activity in the urban environment and the attitude towards it as an informal factor that controls human behavior. It is the urban environment that is a connecting link between a social environment and the space. Its function is to connect an individual and a cultural element of a location, providing the unity of history and space. The methods of urban environment arrangement help an individual not only to identify his physical location, but also to associate himself with a location, culture, which often goes against his virtual standard image.

\section{Purpose}

The task of the research is to analyze theoretical approaches in urban science in order to explore local social and cultural space in the context of globalization. 
The object of the research is contradictions between localization and globalization of the urban environment through the transformation of human identity. The local environment itself is the place to keep the distinctive features as a condition to overcome global unification and standardization in real and virtual space, which are the fundamentals of human existence.

\section{Statement of basic materials}

\section{Cultural self-identification in the age of globalization}

Globalization as an obvious, unbiased, and global process is establishing new single space with certain common rules and laws. This situation probably influences a person in terms of common material and cultural benefits provided by new civilization. In different places of the world people use the same products and services: transportation carriers, foodstuff, banks, social networks, movies, books, music, etc. Technologies and information, produced by modern civilization, unite individuals, establish common and global culture (Mustafina, 2013). This point of view may be doubtful, since the global culture is not an identical and obligatory culture for everybody. For every citizen of the planet, it gives the opportunity to use the benefits and achievements of any national culture (Mezhuev, 2010).

Dichotomous nature of cultural sphere can be revealed when its material, technological and spiritual elements are very close to each other, but at the same time creative, intellectual and reproductive activities are critically distant. It allows for the development of not only technological, political and legal unity of world powers, but also social and cultural space, which is considered to be the threat to national and personal self-identification (Sokolova, 2009). From this perspective, the main characteristic feature is the language, as well as other differences like affiliation with a certain race, nation, demography - representatives of definite social cultural values and attitude, which are the basis of objective reality of a human and humanity. These processes occur in the system of the arranged and changing space of architectural environment. This environment by itself demonstrates the concept of difference, combining all the other distinctive features and creating a particular cultural sphere.

The development of modern civilization and the urban environment, in particular, produced various social institutions: state, law, religion, culture, etc., which, in its turn, caused the depersonalized type of human relations. Legal, economic, administrative and managerial types of relations, established through globalization, are not personalized and it is the reason for the internal personal conflict. The German philosopher Simmel stated that "if a regular external contact of dozens of people in a city gave the same amount of internal response in a town, where almost everyone knows everybody he meets or has appreciative relations, it will be fully atomized internally and get into incredible state of mind" (Wirth, 1997, p. 180). Depersonalized relations, universal cultural standards, unified technological techniques characterize modern architecture and urban space, acting as a new global civilization form, where the unity of humanity is implemented more than ever. It is quite fair to consider that the dialogue of cultures, in terms of their differences, is a proper spiritual and cultural continuation of global processes in the modern world. The dialogue enables different cultures to exist and not to be in conflict with one another. Moreover, the dialogue of cultures is a source of understanding the differences of each culture, its specificity and identity. This identity is reflected in a person, who is also a representative of some culture. However, in the age of globalization an individual, as a product of national community, cannot be limited with products of local culture - he can use the 
achievements of other cultures and become the citizen of the world more than the representative of his specific social group.

The human is the one who reproduces social and cultural concepts and notions. However, understanding the problems of personal existence is the key to understanding global society, since complicated perception of globalization is inside a person, but not beyond (Mustafina, 2013; Stepanyants, 2011). The issue of identity and distinctive features within the dialogue of cultures is the most relevant, because this culture is no more "hidden", isolated from the world and, consequently, is influenced by global trends. This way, once isolated nations nowadays cannot use only conventional methods of space and forms arrangement in architecture: national features are florid and pompous and step back to unified rationality. This characteristic is typical of other cultural features: traditions, cultural product, material benefits, even the language, which can give its way to global languages, taking more and more loan words. Thus, once having identified the features that make the culture distinctive, a person as a representative of this culture reduces its significance, replacing with products of global and more progressive, utilitarian culture.

\section{Interaction between a human and the urban space. Cognitive approach to urban science}

In the global world a human is not only a part of the urban environment, but a creator and a product of this environment at the same time. Urban anthropology determines relationship between a human and the environment and promotes special human mentality in the urban space. A modern city is a place for the dialogue of cultures, where the most part of the population is characterized by certain distinctive features: the more individuals participate in this interaction, the more individual peculiarities are differentiated (Wirth, 1997). Due to the multitude and high density of urban population, residents do not know each other in person, which was not typical of neighboring community before. As a result, there is a segmentation of human relations: an urban citizen depends on a large number of people, but less on definite people (Marchuk \& Rarytskyi, 2019). Social networks in the urban space are used for reaching the goals and are rated according to their benefits. As a result, there is a personality conflict when, on the one hand, an individual becomes free from personal and emotional control from the groups close to him, but on the other hand, he loses his self-expression style, morale and sense of participation, which leads to the feeling of "social vacuum". Along with that, there is a process of personality alienation from culture, where an individual is not holistic, but a functional part. These changes in personal and public existence cause a sense of loss and dissatisfaction. A. Toffler (1990) described that most people nowadays are more skilled in analysis than synthesis. Once E. Durkheim used such a concept as "social fact" in his work "Division of labour", which is understood as a course of action that restricts an individual externally. Such influence can be expressed formally (legal regulation) or informally (moral, religious or family standards). Social facts, according to Durkheim $(1964,1996)$, are endowed with some coercive power, so that they monitor personal behavior. The issue of human behavior in the urban environment is analyzed in the context of cognitive approach to urban science, which is related to a number of informal regulators of social factors.

With the help of cognitive urbanism people are able to cognize and perceive the urban environment, to 'digest' information and respond to its standards through personal behavior. In this case, the individual perception of the environment is principal according to the "stage theory" and identifies a human emotional component (Krasheninnikov, 2017). A model of the 
'stage theory' investigates only not the influence of the urban environment on human behaviour, but conversely - repeating human behavior scenarios can alter the environment. In other words, if a person has to deal with negative urban environment daily, it leads to his behavior scenario. On the contrary, aesthetic and positive urban environment creates its behavior scenario according to the functions and intentions of the architectural environment (Bazaluk \& Kharchenko, 2018).

There is one more variant possible, when a definite conceptual scenario in a neutral urban environment is created by repetitive activities of the residents (for instance, in transport communications). Thus, stable social and spatial complexes - morphotypes of the urban environment are established.

Despite the fact that public urban environment is the object of the research into cognitive approach to urban science, the individual in the "human-environment" system takes a dominant position - he consciously reconstructs urban 'matter' and changes the relations. The key role is given to images, values, creation and communication of information. In this regard, a category "good" can be related to the urban environment only if the continuum of a complex 'urban ecosystem' is not destroyed under changes, and a fundamental benefit is understood as ongoing development of an individual, his competencies and cultural relations progress. With social evolution, there is a sense of relation to spatial environment. The environment itself provides cultural tradition and legacy, promotes a sense of coherence in time and space, supports and improves personal growth (Lynch, 1987). A person cogitates and identifies himself with spatial terms, which are based on esthetic images and associations; he adopts the space and fits himself into it.

\section{Community of global city}

"Global city" is a term introduced by Saskia Sassen in her work "The global city" as concept opposite to the term "metropolis". It characterizes major cities: centers of global management with financial institutions. Currently, there are only three cities in the world London, New-York, Tokyo. A few more claim to get the status - Hong Kong, Beijing, Singapore, Shanghai, Sydney, Paris, Dubai. The cities mentioned are representatives of postindustrial economy more than other megacities. They are the centers for financial and consulting services, media production, and innovations, they outpace the rest of the world (3-5 years), and operate out of touch from the surrounding world in geoeconomic space. In comparison with other global cities they form more progressive postindustrial society, which is of particular interest in this study (Sassen, 2001).

Postindustrial society, appeared in conditions of globalization, is characterized by its round the clock activity (business life, trade, entertainment); high energy consumption; high standards of trade, public catering, commercial real estate; developed public space; new forms of consumer culture (visual consumption, combination of entertainment with other activities). As a result, human existence in postindustrial society is oriented to a certain lifestyle as a subjective, individual and relative model of existence. This model appears when social, cultural and religious patterns structuring human life are diffused. As some schematic solutions to life situations, the lifestyle of an individual is a key to success and appropriateness of his actions and allows a person to conform to the standards of modern behavior. Accumulative symbolic consumption of things that are not vital but have intersubjective values like prestige, authority, popularity, etc. leaves special traces in human lifestyle (Manakova, 2008). There is a necessity in 'audience' to boost self-esteem and self-identification.

Nowadays, virtual social space, generated and promoted with the emergence of information technologies, is a place to reduce personal contacts and destroy traditional social reality. This 
space is becoming a new vital space for social and personal existence with new ways and models of identification. Modern retail formats and services in global cities are intended for more anonymous and depersonalized communication by means of social networks. They intensify separation of virtual human presentation from his genuine personality. Consequently, it leads to a number of virtual personal images in different communication environments. The urban environment, where the type of postindustrial personality is formed, is steadily promoting the standard of living - a network of non-industrial activities is developing, service and entertainment industry is growing in real physical space, as well as in virtual one. This period is characterized by the fast pace of urban cultural life development, separation of an individual from local culture, spiritual freedom and personal ideology, daily activities oriented to personalization. Human behavior is determined by means of commodities, but the consumption itself gets quite a symbolic character. Symbolic consumption means that a person does not use something according to its intended purpose, but due to its symbolic value and meaning (Baudrillard, 2017). But simultaneously, some unique urban space is being created by means of architectural methods. This space is identified with local social and cultural territory; it is related to city residents and reflects them in it. In fact, it is the physical urban space that generates the phenomenon of "social neighborhood" in metropolis in comparison with virtual social space. Initially, the concept of neighborhood appeared in city planning in the 50-60-ies and meant that people met and knew each other personally due to the locality within small territory (about 100 families), later it became the framework for the concept of dividing the urban territory into microdistricts. Further, the idea of local neighborhood was dispelled, since most of social relations turned out to be dispersed over the urban territory, but the vast majority of contacts had blood ties, collaborative work, common interests, but not the place of residence. However, different threats to current urban areas (urban reconstruction, construction of new transportation corridors, business expansion, etc) caused counteraction to protect common interests of residents, who arranged in neighborhoods and developed into big communities. Thus, neighborhood as an inspection means turned into a social phenomenon and a definite type of community. Local communities, as well as identification of an individual with a certain name and a physical location, which is his unique social and cultural environment, are significant elements of a human mental image (Lynch, 1987).

The other feature of global city, directly connected with the present study, is the relation of the city to the globalization, its intensification in particular. The more important the role of the city in global geoeconomic space is, the faster and the more expansive the globalization processes are, which encompasses the urban life even at a local level. Due to the global informational space expansion, acceleration and development of communication, information, the resident of the global city anticipates great interaction and influence of all regions of all over the world, and as a result, participates even virtually in global events. In this case, the person himself is the driving force of globalization.

Considering the growth tendencies in global cities, urbanists expect their further integration into the world economy, independent status of urban territory and development of specific laws, arrangement regulations, and intensification of global identity and competitiveness of the urban environment, transition to the culture of innovations. In these conditions the "loss of reality" in the sphere of public life will become stronger, since information technologies are able to reproduce the reality in all details so accurately that the virtual model is becoming more convenient and appealing than reality itself - hyperreality (Baudrillard, 2017). Under these 
circumstances, the competition between a human virtual image and a genuine personality will increase, symbolic consumption will turn virtual (because it is more beneficial). The place where not all general information will be consumed, but the influence of associative and imaginary component on human consciousness will increase (Manakova, 2008).

\section{Originality}

The scientific originality of the research is to analyze the system "a human - the urban space" and to identify how the local space in conditions of globalization influences the human identity formation. It is claimed that the local urban environment is a place to preserve and form human identity in his physical and virtual existence in the global postindustrial age. The idea about local environment as a spatial complex of human identity features was reasonably grounded.

\section{Conclusions}

Globalization forms and develops quite a few systems of values and models for a human existence due to a multilateral character of world perception and a choice for the most appropriate type of culture in the virtual space. The individual is presented with such behavior models that are transcultural, they are beyond his social and cultural space and contradict the real environment of human existence. These models are often incompatible with the environment that is exposed to intentional standardization and unification of virtual images, which neutralize identity features of local urban spaces. The local urban environment is the environment of distinctive features that represent the identity against standard and unified institutions beyond the culture. Nowadays, the spatial organization of physical existence is a connecting element between real and virtual pattern of human life.

\section{REFERENCES}

Baudrillard, J. (2017). The consumer society: Myths and structures. Sage. (in English)

Bazaluk, O., \& Kharchenko, L. (2018). The Philosophy of the Cosmos as the New Universal Philosophical Teaching about Being. Philosophy and Cosmology, 21, 6-13. DOI: https://doi.org/10.29202/phil-cosm/21/1 (in English)

Durkheim, E. (1964). The Rules of Sociological Method. New York: The Free Press of Glencoe. (in English)

Durkheim, E. (1996). O razdelenii obshchestvennogo truda. Moscow: Kanon. (in Russian)

Krasheninnikov, A. (2017). Scenario-Based Design of the Built Environment. Architecture and Modern Information Technologies, 4(41), 242-256. Retrieved from http://marhi.ru/AMIT/2017/4kvart17/18_krasheninnikov/ index.php (in Russian)

Lynch, K. (1987). A theory of good city form. Cambridge: The MIT Press. (in English)

Manakova, I. Y. (2008). Chelovek v postindustrialnom obshchestve. (Dysertatsiia kandydata filosofskykh nauk). Voronezh State University, Voronezh. (in Russian)

Marchuk, L., \& Rarytskyi, O. (2019). Psycholinguistic Preconditions of Gradation Functioning in the Individual World Picture. Psycholinguistics, 26(2), 278-295. DOI: https://doi.org/10.31470/2309-1797-2019-26-2278-295 (in Ukrainian)

Mezhuev, V. M. (2010). Sudba natsionalnykh kultur v epokhu globalizatsii. In Philosophy in the Dialogue of Cultures (pp. 377-382). Moscow: Progress-Tradition. (in Russian)

Mustafina, T. (2013). Rol sovremennogo cheloveka v globalnom mire. Russian Philosophical Society, 3(67). Retrieved from http://www.intelros.ru/readroom/vestnik-rossijskogo-filosofskogo-obshhestva/ves3-2013/ 21366-rol-sovremennogo-cheloveka-v-globalnom-mire.html (in Russian)

Sassen, S. (2001). The global city: New York, London, Tokyo. Princeton University Press. (in English) 
Sokolova, K. (2009). Transformatsiia sotsialnoho chasu ta prostoru $v$ suchasnomu informatsiinomu suspilstvi. (Dysertatsiia kandydata filosofskykh nauk). Dnipropetrovsk National University of Railway Transport named after Academician V. Lazaryan, Dnipropetrovsk. (in Ukrainian)

Stepanyants, M. (2011). Yedinstvo mira i mnogoobrazie kultur (materialy "kruglogo stola" ukrainskikh i rossiyskikh filosofov). Voprosy Filosofii, 9, 3-33. (in Russian)

Toffler, A. (1990). Future shock. New York: Bantam Books. (in English)

Wirth, L. (1997). Urbanizm as a way life. V. G. Nikolaev, Trans. Sotsialnye i gumanitarnye nauki: Otechestvennaya i zarubezhnaya literatura: Seriya 11: Sotsiologiya, 3, 168-196. (in Russian)

\section{LIST OF REFERENCE LINKS}

Baudrillard J. The consumer society: Myths and structures. Sage, 2017. 224 p.

Bazaluk O., Kharchenko L. The Philosophy of the Cosmos as the New Universal Philosophical Teaching about Being. Philosophy and Cosmology. 2018. Vol. 21. P. 6-13. DOI: https://doi.org/10.29202/phil-cosm/21/1

Durkheim E. The Rules of Sociological Method. New York : The Free Press of Glencoe, 1964. 206 p.

Дюркгейм Э. О разделении общественного труда. Москва : Канон, 1996. 432 с.

Крашенинников А. В. Сценарное проектирование городской среды. Архитектура и Современные Информаиионные Технологии. 2017. № 4 (41). C. 242-256. URL: http://marhi.ru/AMIT/2017/4kvart17/ 18_krasheninnikov/index.php

Lynch K. A theory of good city form. Cambridge : The MIT Press, 1987. $524 \mathrm{p}$.

Манакова И. Ю. Человек в постиндустриальном обществе : дис. ... канд. філос. наук. Воронеж. гос. ун-т. Воронеж, 2008. $226 \mathrm{c}$.

Marchuk L., Rarytskyi O. Psycholinguistic Preconditions of Gradation Functioning in the Individual World Picture. Psycholinguistics. 2019. Vol. 26. No. 2. P. 278-295. DOI: https://doi.org/10.31470/2309-1797-2019-26-2278-295

Межуев В. М. Судьба национальных культур в эпоху глобализации. Философия в диалоге культур. Москва : Прогресс-Традиция, 2010. С. 377-382.

Мустафина Т. Роль современного человека в глобальном мире. Вестник Российского Философского Общества. 2013. № 3 (67). URL: http://www.intelros.ru/readroom/vestnik-rossijskogo-filosofskogo-obshhestva/ ves3-2013/21366-rol-sovremennogo-cheloveka-v-globalnom-mire.html

Sassen S. The global city: New York, London, Tokyo. Princeton University Press, 2001. 480 p.

Соколова К. Трансформачія соціального часу та простору в сучасному інформаџійному суспільстві : дис. ... канд. філос. наук. Дніпропетр. нац. ун-т залізн. трансп. ім. акад. В. Лазаряна. Дніпропетровськ, 2009. $161 \mathrm{c.}$

Степанянц М. Единство мира и многообразие культур (материалы "круглого стола" украинских и российских философов). Вопросы философии. 2011. № 9. С. 3-33.

Toffler A. Future shock. New York : Bantam Books, 1990. 561 p.

Вирт Л. Урбанизм как образ жизни / пер. В. Г. Николаева. Социальные и гуманитарные науки. Отечественная и зарубежная литература. Серия 11: Социология. 1997. № 3. С. 168-196.

\section{I. О. МЕРИЛОВА ${ }^{1 *}$, К. В. СОКОЛОВА ${ }^{2 *}$}

\footnotetext{
1* Придніпровська державна академія будівництва та архітектури (Дніпро, Україна), ел. пошта iryna.merylova@gmail.com, ORCID 0000-0003-2019-0780

${ }^{2 *}$ Придніпровська державна академія будівництва та архітектури (Дніпро, Україна), ел. пошта sokolova.katerina8@gmail.com, ORCID 0000-0002-3158-8957
}

\section{ЛЮДИНА В УРБАНІЗОВАНОМУ ПРОСТОРІ ГЛОБАЛІЗОВАНОГО СВITУ}

Метою дослідження є визначення рис взаємовпливу людини та урбанізованого середовища в умовах глобалізації. Теоретичний базис представляють роботи сучасних представників соціальної філософії та урбаністики, а також дослідження соціологів Чиказької школи. Наукова новизна полягає в аналізі системи "людина - урбанізоване середовище" в контексті визначення впливу локального простору на формування та 
збереження ідентичності людини в умовах глобалізації. Висновки. Сучасні інформаційні технології посилили супутні зміни в культурі, суспільстві та індивідуальній свідомості, надавши їм дійсно глобального характеру у всій його повноті, що призвело до перебудови ціннісно-нормативної орієнтації особистості та кризи ідентичності, характерної для постіндустріального суспільства. Одним із шляхів ііі подолання є гармонізація взаємодії в системі "людина - урбанізоване середовище" як сфері індивідуалізованого простору соціально-культурної ідентичності людини.

Ключові слова: культурна глобалізація; людина; комунікаційний простір; локальна урбаністика; місто; когнітивна урбаністика; криза ідентичності

\author{
И. А. МЕРИЛОВА ${ }^{1 *}$ Е. В. СОКОЛОВА ${ }^{2 *}$ \\ ${ }^{1 *}$ Приднепровская государственная академия строительства и архитектуры (Днепр, Украина), эл. почта \\ iryna.merylova@gmail.com, ORCID 0000-0003-2019-0780 \\ 2* Приднепровская государственная академия строительства и архитектуры (Днепр, Украина), эл. почта \\ sokolova.katerina8@gmail.com, ORCID 0000-0002-3158-8957
}

\title{
ЧЕЛОВЕК В УРБАНИЗИРОВАННОМ ПРОСТРАНСТВЕ ГЛОБАЛИЗИРОВАННОГО МИРА
}

Целью исследования является определение черт взаимовлияния человека и урбанизированной среды в условиях глобализации. Теоретический базис представляют работы современных представителей социальной философии и урбанистики, а также исследования социологов Чикагской школы. Научная новизна заключается в анализе системы "человек - урбанизированная среда" в контексте определения влияния локального пространства на формирование и сохранение идентичности человека в условиях глобализации. Выводы. Современные информационные технологии усилили сопутствующие изменения в культуре, обществе и индивидуальном сознании, придав им действительно глобальный характер во всей их полноте, что привело к перестройке ценностно-нормативной ориентации личности и кризису идентичности, характерному для постиндустриального общества. Одним из путей его преодоления является гармонизация взаимодействия в системе "человек - урбанизированная среда" как сфере индивидуализированного пространства социальнокультурной идентичности человека.

Ключевые слова: культурная глобализация; человек; коммуникационное пространство; локальная урбанистика; город; когнитивная урбанистика; кризис идентичности

Received: 09.06.2020

Accepted: 26.11.2020 